at their polar groups can come together and form hydrophobic compounds.

The interesting feature of this series of papers was the growing roalisation on the part of chemists of the importance of structure, be it molecular, micollar or microscopic. Certainly tho chemistry of the tanning process cannot bo explained without taking structure into account. With the small molecules which usually enter into the better-known reactions of classical organic chemistry, the significance of their stereomotric pattorn is not very conspicuous, but as soon as large colloidal molecules, such as tannins and proteins, havo to be considered, all grades of structure play an important part in controlling the coming together of the active centres of the two interacting components. The great importance of water as playing an active rôle in the chemical processes was also evidently in the minds of most of the speakers. The chemistry of tanning is the chemistry of turning the hydrated and putrescible material, collagen, into the dehydrated material, collagen tannate, with its active centres suppressed and the peptide links protected from the liability of putrefactive attack.
D. J. L.

\title{
Eighth General Conference of Weights and Measures
}

$\mathrm{U}$ NDER the treaty known as the 'Convention du Mètro', made in 1875 and revisod in 1921, 48 delegatos, representing 29 out of the 31 nations now adhering to the Convention, assembled in the historic Salon de l'Horloge, at tho Ministèro des Affaires Etrangères in Paris on October 3, under the presidency of the French Minister of Industry and Commerce, M. Serre, for the opening session of the eighth Conférence Générale des Poids et Mesures.

At the subsequent meotings of the Conference, held at the Bureau International des Poids ot Mesures, Sèvres, under the presidency of M. Cotton, member of the Institut de France, a varied programme of considerable importance to all concerned with precise measurement, whether from an industrial or scientific point of vicw, was transacted.

After receiving the report of the Intornational Committeo on the work of the Bureau for the six years which have elapsed sinco the meetings of the previous Conféronces Générale, the Conforence first authorised the issue of new certificates for those of the national copies of the metre and the kilogramme which had been found, on re-verification, to have varied by more than tho amounts regarded as possibly attributable to experimental error. Incidentally, the recent researches of the Bureau have led to the conclusion that the differences between the coefficients of thermal expansion previously attributed to the various national copies of the metre were probably not real, and that it would bo better to assumo a uniform mean value of the coefficient for all bars constructed from the same melt of the 10 per cent iridio-platinum alloy of which they are made. The Conforence therofore also sanctioned tho issue of amonding certificates giving effect to this change, which, since the bars originally were not actually compared at $0^{\circ} \mathrm{C}$., leads also to certain small changes in their accepted values at this temperature.

The Conference was informed of the results of recent determinations of the length of the metro in terms of the wave-length of the red radiation of cadmium, both at the National Physical Iaboratory in Great Britain, and at the Physikalisch-Technische Reichsanstalt in Germany, and referrod to the International Committee for further study a proposal to adopt a wave-length of visible light as the basis for the future definition of the unit of length.

At the previous Conference a new series of specifications for the international (thermodynamic) scale of temperature was given provisional sanction, and has since been in general use by the principal national laboratories of the world. A number of errata in the text of these specifications were corrected by the recent Conference, which also arranged for the calling of a Special Thermometric Conference to be held under its auspices, at which the details of the specifications could be further considered with the view of their final ratification and adoption at the next general Conference to be held in 1939 .

On the proposition of the Intornational Committee, based on the recommendation of its special Consultative Committee for Eloctricity, the Conference took the important step of adopting, in principle, the eventual substitution of the 'absolute' c.G.S: system of electrical units for the present International System, leaving to the Committee the duty of fixing, in collaboration with the various national laboratorios, the relationships between the old and now units, and the date when the change should become effective. As regards the volt and ampere, the changes involved are not large enough to be of commercial significance at the present time, and it is well that the change should be mado before increased precision in everyday measuroment makes theso significant. As regards the ohm, the change in this unit amounts to a decrease of about 5 parts in 10,000 , which is, of course, approciable in relation to the possible accuracy of comparison of resistance coils, and will therefore need to be taken into account by the makers and users of such instruments.

The Conforence adopted a resolution putting on record that it regards itself, by virtue of tho 1921 revision of the Convention, as the natural successor to the London Conference of 1908 which fixed the present electrical units, and in consequence as having the necessary powers to amend the decisions of that Conference if and when this may be thought necessary.

Following another recommondation of the Consultative Committeo for Electricity, the Conference authorised the International Committe 3 e to constitute a separate Consultative Committee on similar lines to deal with the subject of photometric standards. In the constitution of this new Committee care is to bo taken to secure as close liaison as practicable with the Select Committeo of the International Illumination Commission, and its functions will be strictly limited, at least for the present, to the coordination of the work of the various national laboratorios. 'The adoption of a black body, at the melting point of platinum, as the ultimate standard of luminosity, is envisaged, but all technical details were left, in the first instance, for consideration by the Committee.

A proposal by tho delegate of the U.S.S.R. to establish yet another Consultative Committee, to deal with questions of practical metrology, that is, everyday control of weights and measures for commorcial purposes, was referred back to the Intornational Committee for consideration. J. F. S. 